Sujit K. Pandit MD PHD, Sarla P. Kothary MD, Uma A. Pandit MD, Nadia R. Kunz, PHARMD

\title{
Double-blind placebo-controlled comparison of dezocine and morphine for post- operative pain relief
}

Dezocine, a new mixed agonist-antagonist-type opioid analgesic, was compared in a double-blind trial with placebo and $10 \mathrm{mg}$ of morphine in 190 patients with acute postoperative pain. The medications were given intramuscularly. Dezocine was administered at three dose levels $(5,10$, and $15 \mathrm{mg})$. Pain relief scores, sedation. and side effects were recorded at 15,30,60,120 and 240 min after injection. Significantly higher pain relief scores $(p<0.05)$ were reported for the groups receiving dezocine 10 and $15 \mathrm{mg}$ than the placebo group at all observation times, except for dezocine $15 \mathrm{mg}$ at four hours. Morphine produced significantly better pain relief than placebo only between the second and fourth hour after administration. Significantly better pain relief was obtained with dezocine (10 and $15 \mathrm{mg}$ ) than with morphine during the first hour. The mean four-hour cumulative pain relief scores (TOTPAR) were significantly $(p<$ $0.05)$ higher than placebo for all active treatment groups.

\section{Key words}

ANALGESICS: dezocine, morphine; PAIN: postoperative; OPIOIDS: agonist-antagonist.

From the Department of Anesthesiology, University of Michigan Medical Center, Ann Arbor, Michigan. Presented at the 37th Assembly of the New York State Society of Anesthesiologists in December 1983 in New York.

Supported by a grant from Wyeth Laboratories, Philadelphia.

Address correspondence to: Dr. Sujit K. Pandit, Department of Anesthesiology, Box 043, University of Michigan Hospitals, 1405 E. Ann Street, Ann Arbor, Michigan 48109.
Side effects were few with no significant differences between the treatment groups. Seventy-nine per cent of the patients in the dezocine $15 \mathrm{mg}$ group, and 73,68, 58 and 50 per cent respectively, of the patients in the dezocine $10 \mathrm{mg}$, dezocine $5 \mathrm{mg}$, morphine $10 \mathrm{mg}$ and placebo group had a satisfactory clinical response. Significantly $(p<0.05)$ more patients in the groups receiving dezocine 10 and $15 \mathrm{mg}$ than in the placebo group had a satisfactory clinical response; the difference was not significant for the dezocine $5 \mathrm{mg}$ and morphine $10 \mathrm{mg}$ groups. We conclude that dezocine is a promising and safe analgesic, slightly more potent than morphine on a milligram per milligram basis for the relief of postoperative pain. Dezocine's rapid onset of action after intramuscular injection presents an advantage over morphine.

The need for a potent analgesic with minimum side effects, especially with low dependence liability, led to the introduction of the new opioid agonist-antagonist type of analgesics in clinical practice. Dezocine, a synthetic bridged aminatetralin (Figure), is one of the newer compounds in this category. In standard animal analgesic tests, dezocine was found to be 7 to 18 times as potent as morphine with a therapeutic index of greater than $1000 .^{1,2}$ In addition, it demonstrated slightly less antagonistic activity than nalorphine. ${ }^{1}$ In tests for dependence liability, dezocine did not suppress abstinence in withdrawn morphinedependent monkeys, nor did it produce dependence when administered chronically in monkeys. ${ }^{2}$ In the dog, dezocine was found to possess less potential for producing bronchoconstriction, respiratory de- 
<smiles>CN1CC2CC3C4C=CC(O)C3Oc3c(O)ccc(c34)C21</smiles>

Morphine<smiles>CCOC(=O)C1(c2ccccc2)CCN(C)CC1</smiles>

Meperidine<smiles>CC(C)=CCN1CC2CC3(C)CC2C1(C)Cc1ccc(O)cc13</smiles>

Pentazocine<smiles></smiles>

Butorphanol<smiles>CC1(C)CCC2CCCCC2[C@H]1N</smiles>

Dezocine

FGURE Chemical structures of morphine, meperidine, pentazocine, butorphanol, and dezocine.

pression, hypotension, and histamine-release than either morphine or pentazocine. ${ }^{3}$

In humans, dezocine was 8.6 times as potent as pentazocine in terms of respiratory depressant effects. ${ }^{4}$ In two clinical studies on the drug's analgesic properties, the potency of $10 \mathrm{mg}$ of dezocine was considered to be at least that of $50 \mathrm{mg}$ of meperidine ${ }^{5}$ and of $10 \mathrm{mg}$ of morphine. ${ }^{6}$

Since neither of the previous investigations had used a placebo control group we decided to evaluate the efficacy, relative potency and safety of single intramuscular injections of dezocine as a postoperative analgesic and to compare the effects with those of a placebo and a standard analgesic (morphine).

\section{Methods}

The study was approved by the Committee to Review Grants for Clinical Research and Investigation Involving Human Beings at the University of
Michigan Medical Center, and all patients provided informed consent. A total of 190 adults, ASA physical status class I and II male and female surgical patients who complained of moderate to severe pain, participated in the study. Excluded were women of childbearing potential and patients with a history of narcotic use.

The patients had undergone either general surgical, gynecologic, or orthopaedic procedures under general anaesthesia. Preoperative medication consisted of a tranquilizer (usually diazepam) which was accompanied by morphine or meperidine in 62 per cent of the cases. After induction with thiamylal, anaesthesia was provided by a combination of nitrous oxide-oxygen and either halothane or enflurane. In a few patients, anaesthesia was supplemented by small doses of tranquilizers or opioids. When the patient complained of pain upon emergence from anaesthesia in the recovery room, he or 
she was encouraged to wait for 15 to $30 \mathrm{~min}$ before any analgesic was given. After that time, if the pain persisted, and was judged by the patient to be either moderate or severe, a single intramuscular injection of either dezocine $(5,10$, or $15 \mathrm{mg})$, placebo $(0.9$ per cent $\mathrm{NaCl}$ ), or $10 \mathrm{mg}$ of morphine was administered in a double-blind, random order. Patients who had received an opioid either for premedication or during surgery were excluded from the study unless three hours or more had elapsed since its administration.

The test drugs were supplied in identical ampoules which were numbered consecutively and assigned to the patients in order of their entrance into the study. This was done in ascending order to those with moderate pain and in descending order to those with severe pain. A computer-generated technique was used for randomization.

Vital signs (systolic and diastolic arterial pressure, pulse rate, and respiratory rate) were recorded before medication and every $15 \mathrm{~min}$ for four hours. All preanaesthetic interviews and postoperative observations and assessments were conducted by a single observer.

The baseline pain intensity was assessed using a verbal scale. Patients were asked to rate their pain either as, "mild," "moderate," or "severe." Only patients reporting moderate or severe pain 15$30 \mathrm{~min}$ after their first complaint of pain were admitted into the study.

At $15,30,60,120$, and 240 min after study drug injection, the patients were asked to evaluate the effect of the test medication in terms of per cent pain relief. These evaluations were later scored for statistical analysis as $4=100$ per cent relief; $3=$ more than 50 per cent; $2=50$ per cent relief; $1=$ less than 50 per cent relief; $0=$ no relief; and $-1=$ pain worse. Mean and cumulative mean pain relief (TOTPAR) scores were calculated. The TOTPAR scores were determined by summing the weighted individual pain relief scores over the four-hour observation period. This entailed multiplying the pain relief scores at each observation time by the fraction of an hour since the last observation.

Patients who reported less than 50 per cent relief during the first hour after the injection were encouraged to wait until one hour had passed before receiving additional medication. At $60 \mathrm{~min}$ or beyond, patients with less than 50 per cent relief were offered a rescue analgesic, morphine, 2 to
$4 \mathrm{mg}$ intravenously. The time of such remedication, which terminated study observations on the patient, was recorded; otherwise, the data were to be obtained through four hours. Following the convention of Lasagna ${ }^{7}$ and Houde et al. ${ }^{8}$ these patients were assigned pain relief scores of zero after they were remedicated.

At each observation time, as well as before study drug administration, the degree of sedation was noted and scored as $0=$ none; $1=$ mild; $2=$ moderate; or $3=$ marked. A patient was considered mildly sedated when awake but showing signs of drug activity. Sedation was noted "moderate" when a patient was asleep, but easily aroused with light stimuli such as addressing by name or procedure for taking blood pressure. When nonresponsive to light stimuli, sedation was considered to be "marked." Any observed adverse effects and those elicited by asking non-leading questions were recorded and their relationship to the study medication also was judged.

At the end of the study, the investigator provided an overall clinical judgment as to whether or not the treatment was satisfactory. The analgesic response was considered satisfactory if the study medication provided at lest 50 per cent pain relief for two hours with onset of action within 60 minutes and absence of severe adverse effects.

\section{Statistical analysis}

The demographic variables of age and weight were examined by a one-way analysis of variance, supplemented by the Student-Newman-Keuls test for pairwise comparisons. ${ }^{9}$ The nominal variables of sex, race and surgical procedures were analyzed by the Chi-square test; Fisher's exact test was used for pairwise comparisons whenever the variable under consideration was classified into two levels. ${ }^{10}$ The categorized pain relief scores, at each observation time and cumulatively, were analyzed by the generalized Cochran-Mantel-Haenszel procedure, using marginal ridit scores. ${ }^{1,12}$ The analysis takes the initial pain level as a covariable and provides a test of the average response weighted across the initial pain categories. Pairwise comparisons were made within the context of the generalized Cochran-Mantel-Haenszel procedure, using the ranking based on all therapies and the overall pooled variance terms within each pain category. This nonparametric procedure circumvents the need 
TABLE I Demographic data by treatment group

\begin{tabular}{|c|c|c|c|c|c|}
\hline \multirow[b]{2}{*}{ Characteristic } & \multicolumn{5}{|c|}{ Treatment group } \\
\hline & $\begin{array}{l}\text { Dezocine } \\
5 \mathrm{mg} \\
(n=38)\end{array}$ & $\begin{array}{l}\text { Dezocine } \\
10 \mathrm{mg} \\
(n=37)\end{array}$ & $\begin{array}{l}\text { Dezocine } \\
15 \mathrm{mg} \\
(\mathrm{n}=38)\end{array}$ & $\begin{array}{l}\text { Morphine } \\
10 \mathrm{mg} \\
(\mathrm{n}=39)\end{array}$ & $\begin{array}{l}\text { Placebo } \\
(n=38)\end{array}$ \\
\hline \multicolumn{6}{|l|}{ Age $(y r)$} \\
\hline Mean & 35.0 & 35.0 & 34.6 & 35.3 & 30.7 \\
\hline Range & $20-56$ & $21-56$ & $19-56$ & $18-56$ & $19-56$ \\
\hline \multicolumn{6}{|l|}{ Weight $(k g)$} \\
\hline Mean & 64.7 & 70.0 & 69.7 & 70.0 & 64.4 \\
\hline Range & $47-114$ & $41-103$ & $44-102$ & $46-102$ & $43-106$ \\
\hline \multicolumn{6}{|l|}{ Sex } \\
\hline Male & 9 & 12 & 15 & 12 & 9 \\
\hline Female & 29 & 25 & 23 & 27 & 29 \\
\hline \multicolumn{6}{|l|}{ Surgical procedures } \\
\hline Abdominal & 27 & 25 & 29 & 26 & 24 \\
\hline Orthopaedic & 8 & 8 & 7 & 6 & 6 \\
\hline Other & 3 & 4 & 2 & 6 & 9 \\
\hline \multicolumn{6}{|c|}{ Pre-and/or intraoperative opioids } \\
\hline$\geq 3 \mathrm{hr}$ before study & 27 & $30 * \dagger$ & $29 \dagger$ & 20 & 21 \\
\hline None & 11 & 7 & 9 & 19 & 17 \\
\hline \multicolumn{6}{|l|}{ Initial pain intensiry } \\
\hline Severe & 18 & 18 & 18 & 18 & 18 \\
\hline Moderate & 20 & 19 & 20 & 21 & 20 \\
\hline
\end{tabular}

*Significantly $(\mathrm{p}<0.05)$ different from placebo.

†Significantly $(p<0.05)$ different from morphine.

to assume a normal distribution of the data or that the relief categories represent equal steps.

The proportions with effective (at least 50 per cent) relief, the treatment failure rates, the proportions with a satisfactory investigator's evaluation, the categorized sedation scores, and the proportions with an increased degree of sedation from baseline also were analyzed through the generalized Cochran-Mantel-Haenszel approach. The frequencies of adverse effects were compared among therapy groups by the Chi-square test. The vital signs were examined for changes within groups from the baseline by the paired t-test, while comparisons among the groups were made by a one-way analysis of covariance. ${ }^{9}$

\section{Results}

Demographic data (Table I)

The overall study population consisted of 57 (30 per cent) men and 133 (70 per cent) women; the mean age of the patients was 34.1 years (range 18-56 years) and their mean weight was $67.8 \mathrm{~kg}$ (range 4l-114kg). For 131 ( 69 per cent) patients the operative procedure was abdominal surgery; 35 (18 per cent) had undergone orthopaedic procedures, and in 24 ( 13 per cent) patients a variety of other general surgical procedures had been performed. In combination with other medications, 112 (59 per cent) patients received an opioid (mostly morphine or meperidine) as a premedicant, eight (four per cent) were given either fentanyl or morphine intraoperatively, and seven (four per cent) patients receitred an opioid both pre- and intraoperatively. Significantly more patients $(p<$ 0.05 ) in the dezocine 10 and $15 \mathrm{mg}$ groups had received pre- and/or intraoperative opioids than in the morphine group. The groups receiving dezocine $10 \mathrm{mg}$ and placebo were also significantly $(\mathrm{p}<$ 0.05 ) different. However, a "washout period" of at 
TABLE II Pain relief scores

\begin{tabular}{|c|c|c|c|c|c|c|c|}
\hline \multirow{2}{*}{$\begin{array}{l}\text { Treatment } \\
\text { group }\end{array}$} & \multirow{2}{*}{$\begin{array}{l}\text { No. of } \\
\text { patients* }\end{array}$} & \multicolumn{5}{|c|}{ Mean pain relief scores - time afier treatment } & \multirow{2}{*}{$\begin{array}{l}4 \mathrm{hr} \\
\text { TOTPAR } \\
\text { Scorest }\end{array}$} \\
\hline & & $15 \mathrm{~min}$ & $30 \mathrm{~min}$ & lhr & $2 h r$ & $4 h r$ & \\
\hline Dezocine $5 \mathrm{mg}$ & 37 & 1.1 & 2.0 & 2.2 & 1.8 & $0.7(33)$ & $4.9 \neq(33)$ \\
\hline Dezocine $10 \mathrm{mg}$ & 37 & $1.4 \div 8$ & $2.3 \ddagger 8$ & $2.7 \neq 8$ & $2.2 \ddagger$ & $1.0 \neq(36)$ & $6.4 \neq(36)$ \\
\hline Dezocine $15 \mathrm{mg}$ & 38 & $1.4 \mp \xi$ & $2.3 \neq \S$ & $2.7 \ddagger 3$ & $2.3 \ddagger$ & $0.5(35)$ & $5.5 \pm(35)$ \\
\hline Morphine $10 \mathrm{mg}$ & 39 & 0.7 & 1.5 & 2.1 & $2.0 \ddagger$ & $1.1 \neq(38)$ & $5.8 \neq(38)$ \\
\hline Placebo & 38 & 0.9 & 1.3 & 1.7 & 1.2 & $0.3(35)$ & 3.1 (35) \\
\hline
\end{tabular}

*When different from the total in the group, the number of patients with readings available at an observation time is shown in parentheses.

$\uparrow$ The sample size is the number of patients with readings at all observation times

$\ddagger$ Significantly $(\mathrm{p}<0.05)$ better than placebo.

\$Significantly $(\mathrm{p}<0.05$ ) better than $10 \mathrm{mg}$ of morphine.

least three hours was adhered to for all patients, as required by the study protocol. Before receiving the study medication, 100 (53 per cent) patients had moderate pain and 90 (47 per cent) patients had severe pain. The only other statistically significant differences among the therapy groups were in racial distribution (not shown in table). Significantly ( $p<$ 0.05 ) more patients in the $5 \mathrm{mg}$ dezocine group ( 95 per cent) and in the $10 \mathrm{mg}$ morphine group ( 95 per cent) than in the placebo group ( 74 per cent) were white. Overall, 164 ( 86 per cent) of the patients were white, 18 (nine per cent) were black, and eight (four per cent) were of other racial backgrounds.

\section{Pain relief}

Table II summarizes the mean and cumulative mean pain relief scores (TOTPAR) for the 189 patients who had valid efficacy data (one patient was excluded due to receiving meperidine for three weeks before surgery). Significantly ( $p<0.05$ ) higher relief scores were reported for the groups receiving dezocine $10 \mathrm{mg}$ than for the placebo group throughout the study. These differences were significant $(\mathrm{p}<0.05)$ at all evaluation times for the $15 \mathrm{mg}$ dezocine group, except at the four-hour observation point. Morphine $10 \mathrm{mg}$ was significantly better than placebo only at two and four hours. The four-hour TOTPAR scores for all active groups were significantly $(\mathrm{p}<0.05$ ) higher than those for the palcebo group; the highest scores were obtained in the dezocine $10 \mathrm{mg}$ group, followed by morphine $10 \mathrm{mg}$, dezocine $15 \mathrm{mg}$ and dezocine $5 \mathrm{mg}$. During the first hour, mean relief scores for the 10 and $15 \mathrm{mg}$ dezocine groups were signifi- cantly higher $(p<0.05)$ than those for the morphine group, while patients in the groups receiving $5 \mathrm{mg}$ of dezocine and $10 \mathrm{mg}$ of morphine had similas pain relief scores. The degree of relief reported in each group declined sharply at four hours, at which time at least 62 per cent of the patients in each group had received a rescue analgesic. The best responses at four hours were seen in the $10 \mathrm{mg}$ dezocine and $10 \mathrm{mg}$ morphine groups.

As shown in Table III, the proportions of patients with adequate pain relief (at least 50 per cent) were significantly $(\mathrm{p}<0.05$ ) higher in both the 10 and $15 \mathrm{mg}$ dezocine groups than in the placebo group at $30 \mathrm{~min}$ through two hours. At $15 \mathrm{~min}$ through one hour, significantly $(p<0.05)$ more patients in the 10 and $15 \mathrm{mg}$ dezocine groups experienced adequate pain relief than did those in the $10 \mathrm{mg}$ morphine group. By four hours, the proportions of patients with adequate pain relief in the dezocine groups had dropped sharply and were lower than those in the morphine group.

At all observation times during the first two hours (except for $15 \mathrm{mg}$ of dezocine at $15 \mathrm{~min}$ ) the 10 and $15 \mathrm{mg}$ doses of dezocine showed a statistically significant advantage over placebo in pain relief scores and porportions of patients with effective relief. Morphine $10 \mathrm{mg}$, however, was significantly better than placebo only at two and four hours. Dezocine 10 and $15 \mathrm{mg}$ provided significantly better pain relief than morphine during the first hour of the study.

\section{Sedation}

Mean sedation scores are shown in Table IV. In 
TABLE III Proportions of patients with effective relief

\begin{tabular}{|c|c|c|c|c|c|c|}
\hline \multirow{2}{*}{$\begin{array}{l}\text { Treatment } \\
\text { group }\end{array}$} & \multirow{2}{*}{$\begin{array}{l}\text { No. of } \\
\text { patients* }\end{array}$} & \multicolumn{5}{|c|}{ Time after therapy } \\
\hline & & $15 \min$ & $30 \min$ & $l h r$ & $2 h r$ & $4 h r$ \\
\hline Dezocine $5 \mathrm{mg}$ & 37 & $32.4 \%$ & $64.9 \% \dagger$ & $73.0 \%$ & $56.8 \%$ & $21.2 \%(33)$ \\
\hline Dezocine $10 \mathrm{mg}$ & 37 & $54.1 \% \neq \dagger$ & $83.8 \% \neq \dagger$ & $89.2 \ddagger \dagger$ & $73.0 \ddagger$ & $30.6 \%(36)$ \\
\hline Dezocine $15 \mathrm{mg}$ & 38 & $42.1 \% \dagger$ & $76.3 \% \neq \dagger$ & $89.5 \% \neq \dagger$ & $84.2 \%+8$ & $14.3 \%(35)$ \\
\hline Morphine $10 \mathrm{mg}$ & 39 & $17.9 \%$ & $43.6 \%$ & $66.7 \%$ & $66.7 \% \ddagger$ & $36.8 \% \div \pi(38)$ \\
\hline Placebo & 38 & $28.9 \%$ & $52.6 \%$ & $60.5 \%$ & $36.8 \%$ & $11.4 \%(35)$ \\
\hline
\end{tabular}

*When different from the total in the group, the number of patients with readings available at an observation time is shown in parentheses.

†Significantly $(p<0.05)$ better than $10 \mathrm{mg}$ of morphine.

$\ddagger$ Significantly $(p<0.05)$ better than placebo.

$\$$ Significantly $(\mathrm{p}<0.05)$ better than $5 \mathrm{mg}$ of dezocine.

1Significantly $(p<0.05$ ) better than $15 \mathrm{mg}$ of dezocine.

each treatment group, mean sedation was mild at baseline and increased after therapy. More sedation was seen in the active therapy groups than in the placebo group. This difference was significant $(\mathrm{p}<$ 0.05 ) in all 3 dezocine groups at $30 \mathrm{~min}$ and in the dezocine 10 and $15 \mathrm{mg}$ groups at one hour. The $10 \mathrm{mg}$ morphine group had significantly more sedation than the placebo group at two hours and than the dezocine $15 \mathrm{mg}$ group at four hours.

\section{Overall evaluation}

A satisfactory physician's overall evaluation was made for 50 per cent of the patients receiving placebo, 59 per cent of the patients receiving $10 \mathrm{mg}$ of morphine, and 68,73 , and 79 per cent, respectively, of the patients receiving 5,10 , and $15 \mathrm{mg}$ of dezocine. There were significant $(p<0.05)$ differences between the values for the 10 and $15 \mathrm{mg}$ dezocine groups and those for the placebo group.

\section{Adverse effects}

Adverse effects which were considered by the investigator to be probably or possibly related to the study medication were experienced by eight per cent of the patients receiving placebo, ten per cent of the patients receiving morphine $10 \mathrm{mg}$, and 13 , 5 , and 8 per cent of the patients receiving 5,10 , and $15 \mathrm{mg}$ of dezocine, repectively. The most commonly reported drug related adverse effect was nausea, which occurred in three patients given $5 \mathrm{mg}$ of dezocine, one given $10 \mathrm{mg}$ of dezocine, two given $15 \mathrm{mg}$ of dezocine, four given $10 \mathrm{mg}$ of morphine, and one given placebo. Two patients experienced severe adverse effects: one patient who received $10 \mathrm{mg}$ of morphine had severe giddiness, sweating, facial flushing, and a feeling of warmth after therapy, and one patient who received $5 \mathrm{mg}$ of dezocine developed tachycardia (to maximum of 112 beats/min at two hours). These effects subsided spontaneously. Other adverse effects that were related to therapy were bradycardia, decreased blood pressure, dizziness, and vomiting; there were no more than two episodes of each of these symptoms within a given treatment group, and there were no significant differences among the groups with regard to the frequency of any adverse experience.

\section{Vital sign measurements}

There were several significant between-group changes in vital signs, particularly in pulse and respiratory rates; however, these were minor and of no clinical importance. No individual patient had clinically significant changes in vital signs.

\section{Discussion}

It is generally recognized that postoperative pain is inefficiently treated by physicians and nurses. Utting and Smith ${ }^{13}$ in a recent review article quoted several letters, articles and editorials which castigated our attitude towards postoperative pain. An editorial $^{14}$ in Lancet described our practice as "tight-fisted analgesia." The major cause of this attitude by the medical profession is their fear of the side effects of the narcotic analgesics, especially of respiratory depression and addiction liability. Due 
TABLE IV Mean sedation scores and percentages of patients with increased degree of sedation from baseline

\begin{tabular}{|c|c|c|c|c|c|c|c|}
\hline \multirow{2}{*}{$\begin{array}{l}\text { Treatment } \\
\text { group }\end{array}$} & \multirow{2}{*}{$\begin{array}{l}\text { No. of } \\
\text { patients* }\end{array}$} & \multicolumn{6}{|c|}{ Time after therapy } \\
\hline & & Baseline & $15 \mathrm{~min}$ & $30 \min$ & $1 \mathrm{hr}$ & $2 \mathrm{hr}$ & $4 h r$ \\
\hline Dezocine $5 \mathrm{mg}$ & 38 & 0.9 & $\begin{array}{c}1.4 \\
(44.7 \%)\end{array}$ & $\begin{array}{c}1.8 \div \\
(68.4 \%)\end{array}$ & $\begin{array}{c}1.8 \\
(71.1 \%)\end{array}$ & $\begin{array}{l}1.5(31) \\
(48.4 \%)\end{array}$ & $\begin{array}{c}1.2(9) \\
(33.3 \%)\end{array}$ \\
\hline Dezocine $10 \mathrm{mg}$ & 37 & 1.0 & $\begin{array}{c}1.5 \\
(48.6 \%)\end{array}$ & $\begin{array}{c}1.9 \dagger \\
(64.9 \%)\end{array}$ & $\begin{array}{c}2.0 \dagger \\
(70.3 \%)\end{array}$ & $\begin{array}{l}1.6(32) \\
(50.0 \%)\end{array}$ & $\begin{array}{c}1.3(14) \\
(42.9 \%)\end{array}$ \\
\hline Dezocine $15 \mathrm{mg}$ & 38 & 0.9 & $\begin{array}{c}1.7 \\
(50.0 \%)\end{array}$ & $\begin{array}{c}1.9 \dagger \\
(68.4 \%)\end{array}$ & $\begin{array}{c}2.0 \dagger \\
(73.7 \%)\end{array}$ & $\begin{array}{l}1.6(36) \\
(52.8 \%)\end{array}$ & $\begin{array}{c}0.8(9) \\
(22.2 \%)\end{array}$ \\
\hline Morphine $10 \mathrm{mg}$ & 39 & 0.8 & $\begin{array}{c}1.3 \\
(43.6 \%)\end{array}$ & $\begin{array}{c}1.6 \\
(56.4 \%)\end{array}$ & $\begin{array}{c}1.8 \\
(69.2 \%)\end{array}$ & $\begin{array}{l}1.8 \dagger(32) \\
(68.8 \%)\end{array}$ & $\begin{array}{l}1.8 \ddagger(14) \\
(78.6 \%)\end{array}$ \\
\hline Placebo & 38 & 0.9 & $\begin{array}{c}1.1 \\
(21.1 \%)\end{array}$ & $\begin{array}{c}1.2 \\
(36.8 \%)\end{array}$ & $\begin{array}{c}1.5(35) \\
(54.3 \%)\end{array}$ & $\begin{array}{c}1.3(23) \\
(43.5 \%)\end{array}$ & $\begin{array}{c}1.3(6) \\
(33.3 \%)\end{array}$ \\
\hline
\end{tabular}

${ }^{a}$ The percentage of patients with an increased degree of sedation from baseline is given in parentheses under the mean sedation score for each observation time.

*When different from the total in the group, the number of patients with readings available at an observation time is shown in parentheses.

†Significantly $(\mathrm{p}<0.05)$ higher than placebo.

$\ddagger$ Significantly $(\mathrm{p}<0.05$ ) higher than dezocine $15 \mathrm{mg}$.

to their ceiling effect on respiratory depression and lower dependence liability, the opioid agonistantagonist agents would appear to be the analgesics of choice. However, all three agents currently in use in the United States (pentazocine, butorphanol, nalbuphine) have one or more disadvantages such as limited analgesic potency, adverse haemodynamic effects, and psychotomimetic effects. ${ }^{15} \mathrm{Ac}$ tivity at the sigma receptor seems to be responsible for the latter. Dezocine, also an agonist-antagonist opioid, has been characterized as a partial mureceptor agonist with some delta receptor activity but devoid of kappa and sigma receptor activity,* and thus should have less propensity to produce psychotomimetic effects than the currently available agonist-antagonists.

The high placebo response found in the current study (50 per cent satisfactory overall evaluation) may appear surprising. However, postoperative pain is a highly subjective sensation with large components of anxiety and fear mixed with the pain. The anxiety and fear are usually related to the anticipated outcome of the operation, and sequelae thereof and are easily alleviated by the greater attention given to postoperative patients participating in an analgesic trial. A similar magnitude of

*Personal communication, S.H. Snyder, Johns Hopkins School of Medicine, Baltimore. placebo response has been found by others. ${ }^{16-18}$ There is some evidence that placebo and morphine have in part a common pathway mechanism via the endogenous opioid peptide system. ${ }^{19}$ Neither of the two clinical reports on dezocine published earlier ${ }^{5,6}$ were of studies that used a placebo control.

The results of this study show that single intramuscular injections of 5,10 , or $15 \mathrm{mg}$ of dezocine produced consistently better pain relief than placebo. The differences were significant $(p<0.05)$ at all evaluation times for the dezocine $10 \mathrm{mg}$ group and through two hours for the dezocine $15 \mathrm{mg}$ group. In the morphine $10 \mathrm{mg}$ group significantly $(p<0.05)$ higher pain relief scores were seen at the two- and four-hour observation only. These results would indicate that dezocine is a faster-acting analgesic than morphine with a shorter duration of action. These findings are also substantiated by the time-effect curve of the sedation scores. The physicians' overall evaluation favoured dezocine in a dose-dependent order, but a dose repsonse in terms of pain relief scores and percentage of patients with effective relief was apparent only at the two-hour observation. Further clinical studies utilizing additional analgesic parameters (e.g., a four-point verbal pain intensity and visual pain analog scale) and a longer period of observation (e.g., at $\frac{1}{4}, \frac{1}{2}, 1,2,3,4,5,6$ hours) are necessary to investigate the differences between $10 \mathrm{mg}$ and 
$15 \mathrm{mg}$ of dezocine. Since only one dose of morphine was employed in this trial and because of the different time course of the two drugs, a relative potency estimate is difficult. Both 10 and $15 \mathrm{mg}$ of dezocine produced significantly more peak analgesia than $10 \mathrm{mg}$ of morphine. The four-hour cumulative pain relief scores (TOTPAR) for the morphine $10 \mathrm{mg}$ group were between those for the $5 \mathrm{mg}$ and $10 \mathrm{mg}$ dezocine groups.

Adverse reactions were very few, with no statistically significant differences between the treatment groups.

We conclude that dezocine is a promising new opioid analgesic, significantly $(p<0.05$ ) superior to placebo at the 10 and $15 \mathrm{mg}$ dose and slightly more potent than morphine on a milligram per milligram basis for the relief of postoperative pain. Dezocine's rapid onset of action after intramuscular injection presents an advantage over morphine. Further clinical studies to characterize the action of dezocine are needed to confirm these observations.

\section{References}

1 Freed ME, Potoski JR, Freed EH, Conklin GL, Malis JL. Bridged aminotetralins as novel potent analgesic substances. J Med Chem 1973; 16: 595-9.

2 Malis JL, Rosenthale ME. Gluckman MI. Animal pharmacology of Wy-16,225, a new analgesic agent. J Pharmacol Exp Ther 1975; 194: 488-98.

3 Lewis AJ, Kirchner T. A comparison of the cardiorespiratory effects of ciramadol, dezocine, morphine and pentazocine in the anesthetized dog. Arch Int Pharmacodyn 1981; 250: 73-83.

4 Wuest HP, Bellville JW. The respiratory effects of dezocine and pentazocine in man. J Clin Pharmacol 1979; 19: 20S-10

5 Fragen RJ, Caldwell N. Comparison of dezocine (Wy-16,225) and meperidine as postoperative analgesics. Anesth Analg 1978; 57: 563-6.

6 Downing JW, Brock-Utne JG, Barclay A, Schwegmann IL. Wy-16,225 (dezocine), a new synthetic opiate agonist-antagonist and potent analgesic: comparison with morphine for relief of pain after lower abdominal surgery. Br J Anaesth 1981; 53: 59-64.

7 Lasagna L. The evaluation of analgesic compounds in patients suffering from postoperative pain. In: Lasagna $L$, ed.: International Encyclopedia of Pharmacology and Therapeutics, New York, Pergamon Press, 1966; Sect. 6: 51-8.
8 Houde RW, Wallenstein SL, Beaver WT. Evaluation of analgesics in patients with cancer pain. In: Lasagna L, ed.: International Encyclopedia of Pharmacology and Therapeutics, New York, Pergamon Press 1966; SEction 6: 59-97.

9 Steele RGD, Torrie JH. Principles and procedures of statistics. New York, McGraw Hill Book Co. 1960.

10 Sokal RR, Rohlf FJ. Biometry. San Francisco: W.H. Freeman 1969.

11 Landis JR, Cooper MM, Kennedy T, Koch GG. A computer program for testing average partial association in three-way contingency tables (PARCAT). Proceedings of the Statistical Computing Section of the American Statistical Association 1972; pp. 157-62.

12 Landis JR, Heyman ER, Koch GG. Average partial association in three-way contingency tables: $A$ review and discussion of alternate tests. Int Statistical Rev 1978; 46: 237-54.

13 Utting JE, Smith JM. Postoperative Analgesia. Anaesthesia 1979, 34: 320-32.

14 Editorial. Tight-fisted analgesia. Lancet 1976, 1: 1338.

15 Moldenhauer, CC. New Narcotics in Cardiac Anesthesia. In: Kaplan JA, ed.: Cardiovascular Pharmacology, Vol II, New York, Grune \& Stratton 1983; pp 31-78.

16 Egbert $L D$, Battit GE, Welch $C E$, Bartlett $M K$. Reduction of postoperative pain by encouragement and instruction of patients. N Engl J Med 1964; 270: 828-7.

17 Houde RW, Wallenstein SL, Roger A. Clinical pharmacology of analgesics 1 . A method of assaying analgesic effects. Clin Pharmacol Ther 1960; 1 : 163-74.

18 Levine JD, Gordon NC, Fields HL. The mechanism of placebo analgesia. Lancet $1978 ; 2: 654-7$.

19 Levine JD, Gordon NC, Smith R, Fields RL. Analgesic responses to morphine and placebo in individuals with postoperative pain. Pain 1981; 10 : 379-89. 
Résumé

Le dezocine, un nouvel analgésique opiacé mixte ayant les caractéristiques d'agoniste-antagoniste, a été comparé dans une étude à double insu avec du placebo et $10 \mathrm{mg}$ de morphine chez 190 patients accusants des douleurs post opératoire aigues. Les médicaments ont été administré par voie intramusculaire. Le dezocine a été administré à trois doses differentes $(5,10$ et $15 \mathrm{mg})$. Le degré de soulagement de la douleur, sédation, et effets secondaires ont été enregistré à 15,30,60, 120 et 240 min après injection. Un degré de soulagement de la douleur significativement supérieur $(p<0.05)$ a été observé pour le groupe recevant le dezocine à 10 et $15 \mathrm{mg}$ comparativement au groupe placebo et ce d tous les temps d' observation à l' exception de la dezocine $15 \mathrm{mg}$ à quatre heurs. La morphine a produit significativement un meilleur soulagement de la douleur que le placebo uniquement entre la deuxième et la quatrième heure après administration. Un meilleur soulagement de la douleur a été significativement obtenu avec le dezocine 110 et $15 \mathrm{mg}$ ) qu' avec la morphine durant la première heure. La moyenne cumulative pour quatre heures du degré de soulagement de la douleur (TOTPAR) a été significativement $(p<0.05$ ) supérieur au placebo pour tous les groupes traités activement. Les effets secondaires étaient rare et ne présentaient aucune différence significative entre les groupes. Soixante dix-neuf pour cent de patients dans le groupe dezocine à $15 \mathrm{mg}$, et 73, 68,58 et 50 pour cent respectivement, des patients dans le groupe dezocine $10 \mathrm{mg}$, dezocine $5 \mathrm{mg}$, morphine $10 \mathrm{mg}$ et groupe placebo ont démontré les réponses cliniques satisfaisantes. Plus de patients dans le groupe recevant la dezocine 10 et $15 \mathrm{mg}$ que ceux du groupe placebo ont démontré des réponses cliniques satisfaisantes et statistiquement significatives $(p<0.05)$. Aucune différence statistiquement significative fut notée pour le groupe dezocine $5 \mathrm{mg}$ et morphine $10 \mathrm{mg}$. On conclut que le dezocine est un analgésique prometteur et sécuritaire, et légèrement plus puissant que la morphine $\mathrm{mg} / \mathrm{mg}$ pour le soulagement de la douleur en période post opératoire. Le début d'action rapide du dezocine après injection intramusculaire présente un avantage comparativement à la morphine. 